[white paper]

Diamond Open Access

\title{
Epigenética: \\ Ligando e desligando os genes
}

\author{
Colaboração Ciência Aberta1 \\ 26 de Julho de 2021
}

\begin{abstract}
Resumo
Apresentamos uma tradução do artigo [1], que trata sobre epigenética, sobre como o DNA está organizado nas células, o epigenoma das plantas e aplicações.
\end{abstract}

palavras-chave: epigenética, DNA, epigenoma, célula, planta

A versão mais atualizada deste artigo está disponível em

https://osf.io/zx4ne/download

https://zenodo.org/record/5137818

\section{Preâmbulo}

1. Este artigo foi elaborado a partir de [1], seguindo as diretrizes da licença Creative Commons [2].

2. A referência [1], em português, pode ser lida em https://bit.ly/3BFfnFa.

${ }^{1}$ Todos os autores com suas afiliações aparecem no final deste artigo. 


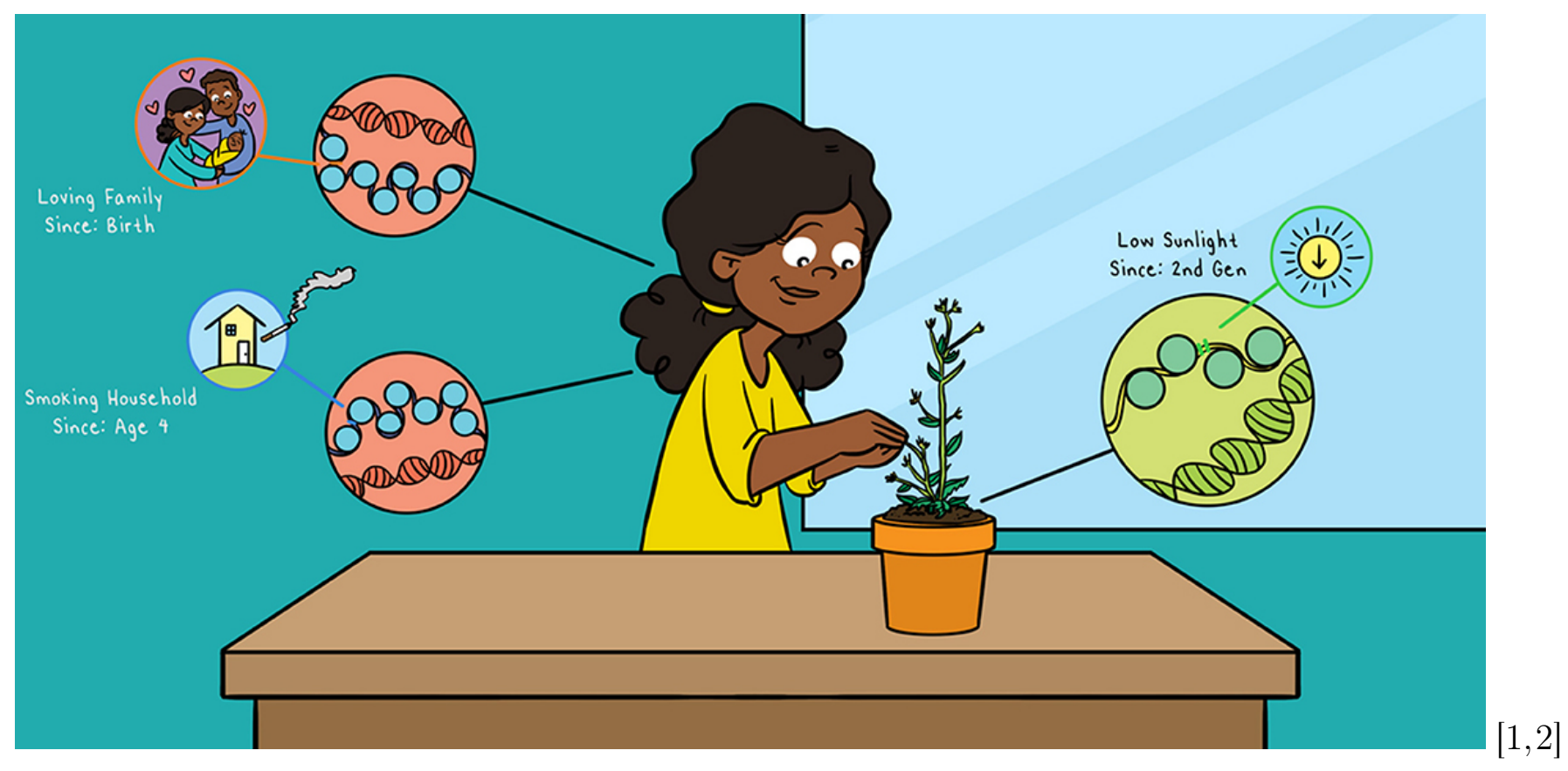

\section{Glossário}

3. Histonas

Proteínas associadas ao DNA que o empacotam e o organizam no núcleo das células.

4. Nucleossomo

Seção do DNA envolvida em torno de oito histonas.

5. Cromatina

Estrutura feita de DNA e proteínas que permite que o DNA seja compactado no núcleo.

6. Epigenética

Estudo das mudanças no DNA que não envolvem mudanças na sequência do DNA.

7. Epigenoma

A descrição completa de todas as modificações epigenéticas do DNA e histonas dentro do genoma de um organismo. 
8. Modificações epigenéticas Adições reversiveis de grupos químicos ao DNA ou às histonas. Essas modificações podem ser transmitidas para a próxima geração.

\section{Síntese}

9. O DNA de uma célula humana possui todas as informações necessárias para produzir mais de 20.400 proteínas diferentes.

10. Esta informação está escrita em uma quantidade de DNA que, se esticada de ponta a ponta, mede cerca de um metro.

11. Você pode imaginar como é desafiador manter todas essas informações de forma organizada.

12. Outros animais, bactérias e plantas enfrentam o mesmo desafio.

13. As soluções para o problema da organização do DNA encontradas pelas células incluem compactar o $\boldsymbol{D N A}$ e ativar $\boldsymbol{e}$ desativar os genes, conforme necessário.

14. O estudo dessas opções é chamado de epigenética.

15. A epigenética é uma área de pesquisa em rápido crescimento e que está modificando nossa compreensão sobre informação genética.

\section{Questionamentos}

16. Você sabe por que nossos corpos têm partes tão diferentes, como pele, olhos e coração, mesmo que quase todas as nossas células tenham o mesmo DNA?

17. Importante: É porque diferentes partes do nosso DNA são" "ligadas" e "desligadas" em células diferentes!

18. Você gostaria de entender isso melhor? 
19. Então, vamos dar uma olhada em como o DNA está organizado dentro das células do corpo.

\section{Como o DNA está organizado nas células?}

20. Quase todas as células do corpo têm o mesmo DNA.

21. O DNA está bem compactado em espirais super apertadas no núcleo.

22. Essa é uma ótima solução para resolver o problema de encaixar uma molécula terrivelmente longa no minúsculo espaço do núcleo.

23. O núcleo de uma célula tem um diâmetro de apenas cerca de um décimo de um fio de cabelo humano!

24. Você pode imaginar caber em um espaço tão pequeno, uma quantidade de DNA (humano) que, se esticado de ponta a ponta, mediria aproximadamente um metro de comprimento?

25. Nesta forma compacta, o DNA é envolvido em torno de proteínas chamadas histonas, como um barbante ao redor de um ioiô (Fig. 1).

26. O envoltório tem um padrão preciso, perfazendo menos do que duas voltas de DNA enrolado em um conjunto de oito histonas.

27. Pode parecer estranho que a adição de proteínas torne o DNA mais compacto.

28. Mas você já tentou guardar uma mangueira de jardim?

29. Nesse caso, você sabe que enrolá-la em um carretel de mangueira torna o trabalho muito mais fácil.

30. O DNA é envolvido em torno de oito histonas, que formam uma estrutura chamada nucleossomo.

31. Todos os nucleossomos juntos formam o que é chamado de cromatina [3]. 

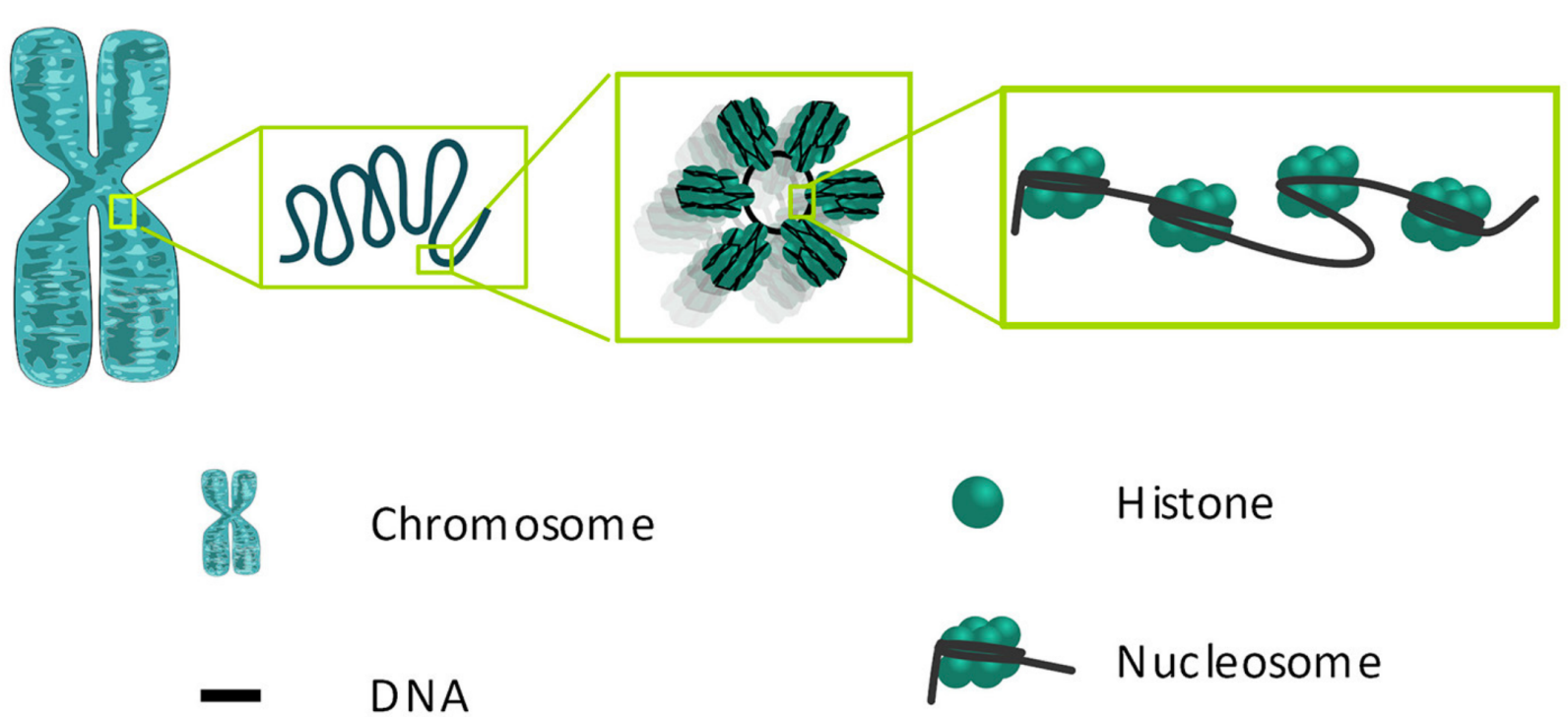

Figura 1: Como o DNA é empacotado no núcleo. O DNA está envolvido em conjuntos de oito proteínas chamadas histonas, formando estruturas chamadas nucleossomos. Todos os nucleossomos juntos no núcleo de uma célula formam o que é chamado de cromatina. Crédito da imagem $[1,2]$. 


\section{Como um DNA bem embalado é acessível?}

32. Os cientistas estimam que o genoma humano tenha mais de 20.400 genes que contêm informações para a formação de proteínas.

33. Isso parece muito, mas as proteínas são extremamente importantes para o bom funcionamento e desenvolvimento de nossos corpos, por isso precisamos de todas essas proteínas.

34. Mas não precisamos de todas elas ao mesmo tempo, seria difícil para uma célula lidar com a produção e o gerenciamento de tantos tipos de proteínas simultaneamente.

35. Assim, somente algumas proteínas são produzidas ao mesmo tempo em uma célula.

36. Isso significa que apenas alguns genes estão ativos ("ligados"), em qualquer célula.

37. Os genes que estão "ligados" determinarão o que aquela célula pode fazer - a função da célula.

38. Alguns genes precisam estar ativos em mais de uma parte do corpo ou tipo de célula, enquanto outros genes estão ativos apenas em células específicas.

39. O DNA bem embalado, enrolado firmemente em torno das histonas, não é acessivel à maquinaria celular que lê as informações no DNA e as transforma em proteinas.

40. Imagine um livro com algumas páginas unidas por um clipe de papel.

41. Você não pode ler o que está nessas páginas!

42. Elas devem estar acessíveis para que você possa lê-las.

43. A embalagem do DNA opera da mesma forma. 
44. As porções da cromatina que precisam ser lidas devem se tornar acessiveis ou abertas.

45. O processo de abertura determina quais genes estarão ativos (onde a cromatina está acessível) ou inativos (onde a cromatina não está acessível).

46. Esse processo é importante para o bom funcionamento de todas as células

47. Ele envolve complexos de proteínas que tornam o DNA acessível a outras proteínas que podem, então, ler as informações no DNA ou reparar qualquer dano.

48. Durante a abertura da cromatina, os complexos de proteínas modificam o DNA e as histonas, adicionando pequenos grupos químicos (Fig. 2).

49. Esses grupos químicos alteram a forma como os nucleossomos interagem entre si, afetando a estrutura da cromatina naquela região.

50. Os grupos químicos também podem enfraquecer as interações entre histonas e DNA.

51. Isso faz com que as histonas deslizem ao longo do DNA ou se desenrolem dele, deixando-o acessível.

52. Os cientistas ainda estão tentando entender como os complexos de proteinas selecionam quais nucleossomos modificar.

53. O estado da cromatina (se está aberta ou não) muda constantemente.

54. Após a fertilização de um ovo, complexos de proteínas dos pais orientam as primeiras modificações. 

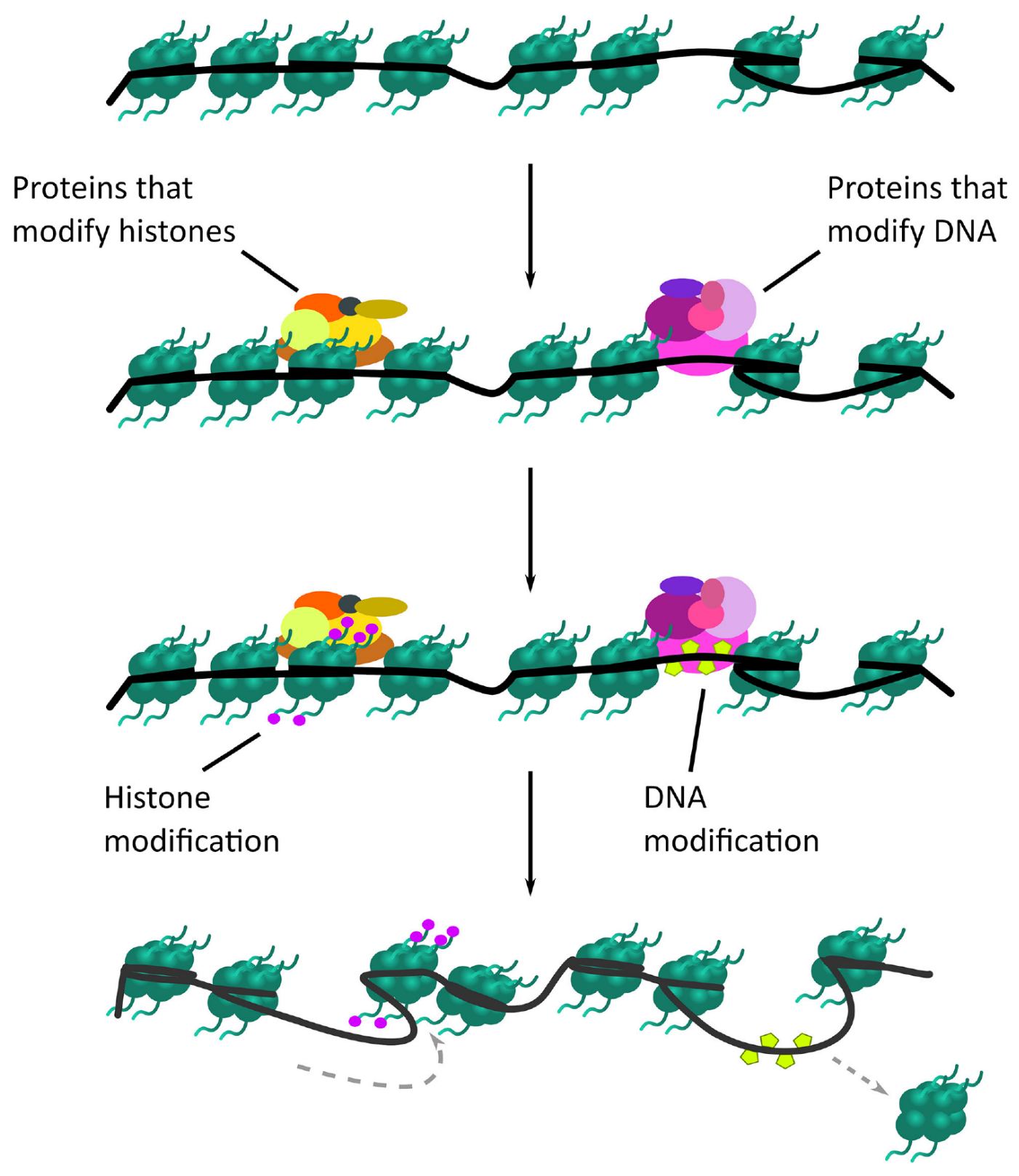

Figura 2: Como a cromatina é aberta. Um gene é ativado "quando" a porção da cromatina onde ele está localizado "se abre". Esse processo envolve proteínas que adicionam pequenas modificações químicas às histonas ou ao DNA. As modificações fazem com que a histona deslize no DNA ou que o DNA se desenrole da histona, permitindo que a cromatina se abra e as informações sobre o gene sejam lidas. 
55. Nos primeiros estágios de desenvolvimento, o DNA do embrião assume o controle e, então, passa a controlar quais porções da cromatina serão abertas e fechadas.

56. A descoberta dessas modificações atraiu a atenção de cientistas e uma nova área de pesquisa nasceu, a epigenética.

57. Epigenética significa "acima" ou "em cima" da genética.

58. Ela se refere a modificações que não afetam a sequência do próprio DNA, mas, ainda assim, têm um efeito significativo sobre os genes que estão ativos.

59. Epigenoma é o nome dado à descrição completa de todas essas modificações epigenéticas.

\section{Quanto tempo duram essas modificações?}

60. Muitos fatores influenciam o epigenoma de um organismo, como idade, meio ambiente, estilo de vida e estado de saúde.

61. Modificações epigenéticas causadas por esses fatores podem ser "memorizadas" por longos períodos.

62. Quando uma célula se divide, suas modificações epigenéticas são passadas para a próxima geração de células.

63. É interessante notar que essa situação é diferente nas células reprodutivas.

64. A maioria das modificações epigenéticas são apagadas durante a reprodução.

65. Em animais, as modificações que persistem duram apenas cerca de uma ou duas gerações. 
66. O epigenoma de um organismo é fluido, o que significa que está em constante mudança.

67. O epigenoma é moldado em resposta ao estresse, de maneiras que duram de horas a meses, anos ou uma vida inteira.

68. Por exemplo, o epigenoma de camundongos expostos a situações muito estressantes pode mudar.

69. Essas mudanças podem afetar seu comportamento; os ratos podem ficar deprimidos por dias ou várias semanas [4].

70. Nas pessoas, há influência do meio ambiente em seus epigenomas.

71. Por exemplo, uma pessoa com uma dieta saudável ou uma vida com pouco estresse terá um epigenoma diferente de alguém com uma dieta não saudável ou uma vida estressante.

\section{As plantas também têm epigenomas?}

72. Você deve estar se perguntando se as mudanças epigenéticas ocorrem apenas em células animais.

73. Todos os organismos, incluindo bactérias e até plantas, têm alterações epigenéticas.

74. O estudo da epigenética em plantas tem uma longa e rica história.

75. A diversidade de maneiras pelas quais as plantas modificam seus epigenomas é notável.

76. As plantas são mestres na modificação epigenética!

77. Como são incapazes de se mover para escapar de seus arredores, as plantas precisam lidar com todos os tipos de condições naturais. 
78. As modificações epigenéticas ajudam as plantas a se adaptarem a essas condições.

79. Nas plantas, as modificações epigenéticas podem persistir por muitas gerações.

80. Isso é fascinante para os cientistas!

81. Eles se perguntam se herdar essas modificações contribui para a diversidade e evolução das plantas.

82. Ou, talvez, as modificações ajudem as plantas a se adaptarem às novas condições.

83. Manter as modificações epigenéticas pode ajudar as populações de plantas a ter tempo suficiente para explorar como cada modificação afeta o número de sementes que produzem, por exemplo.

\section{Epigenética e estresse de plantas}

84. Os cientistas de plantas estão usando uma planta chamada Arabidopsis para responder a muitas questões importantes sobre a epigenética, por exemplo, como as mudanças epigenéticas são geradas e como são herdadas.

85. A Arabidopsis é ideal para isso; ela cresce rapidamente - leva menos de 3 meses para completar um ciclo de crescimento completo, desde ser uma semente até a produção de sementes.

86. Essa planta pode se autofecundar, o que significa que o pólen de uma flor pode polinizar a mesma flor que a produziu.

87. Em um experimento, os cientistas testaram quantas gerações, as mudanças epigenéticas duram.

88. Eles cruzaram duas plantas Arabidopsis que tinham sequências de DNA idênticas, mas epigenomas diferentes (Fig. 3). 
89. Em seguida, pegaram as plantas geradas por esse cruzamento e as autofecundaram por muitas gerações.

90. Incrivelmente, constataram que após dez gerações, as diferenças epigenômicas ainda estavam presentes!

91. Além disso, as mudanças epigenéticas herdadas faziam com que as plantas fossem diferentes umas das outras em certas características.

92. Por exemplo, algumas plantas eram mais altas, floresciam mais cedo ou eram mais tolerantes ao sal do solo $[5,6]$.

93. A partir dos resultados deste e de experimentos semelhantes, os cientistas acreditam que a epigenética é importante na diversidade e evolução das plantas.

94. Esse conhecimento pode ser usado para fazer colheitas melhores! Muitas possibilidades estão sendo exploradas. Tempos emocionantes!

\section{Aplicações de estudos epigenéticos}

95. Os estudos epigenéticos têm muitas aplicações.

96. Eles explicam as variações entre os organismos e suas respostas ao meio ambiente.

97. Eles nos ajudam a entender como a natureza influencia as variações na forma e no comportamento dos seres vivos.

98. Eles explicam como essas variações passam de uma geração para a outra.

99. Agora você sabe que a epigenética pode explicar como as partes de nossos corpos são tão diferentes umas das outras. 


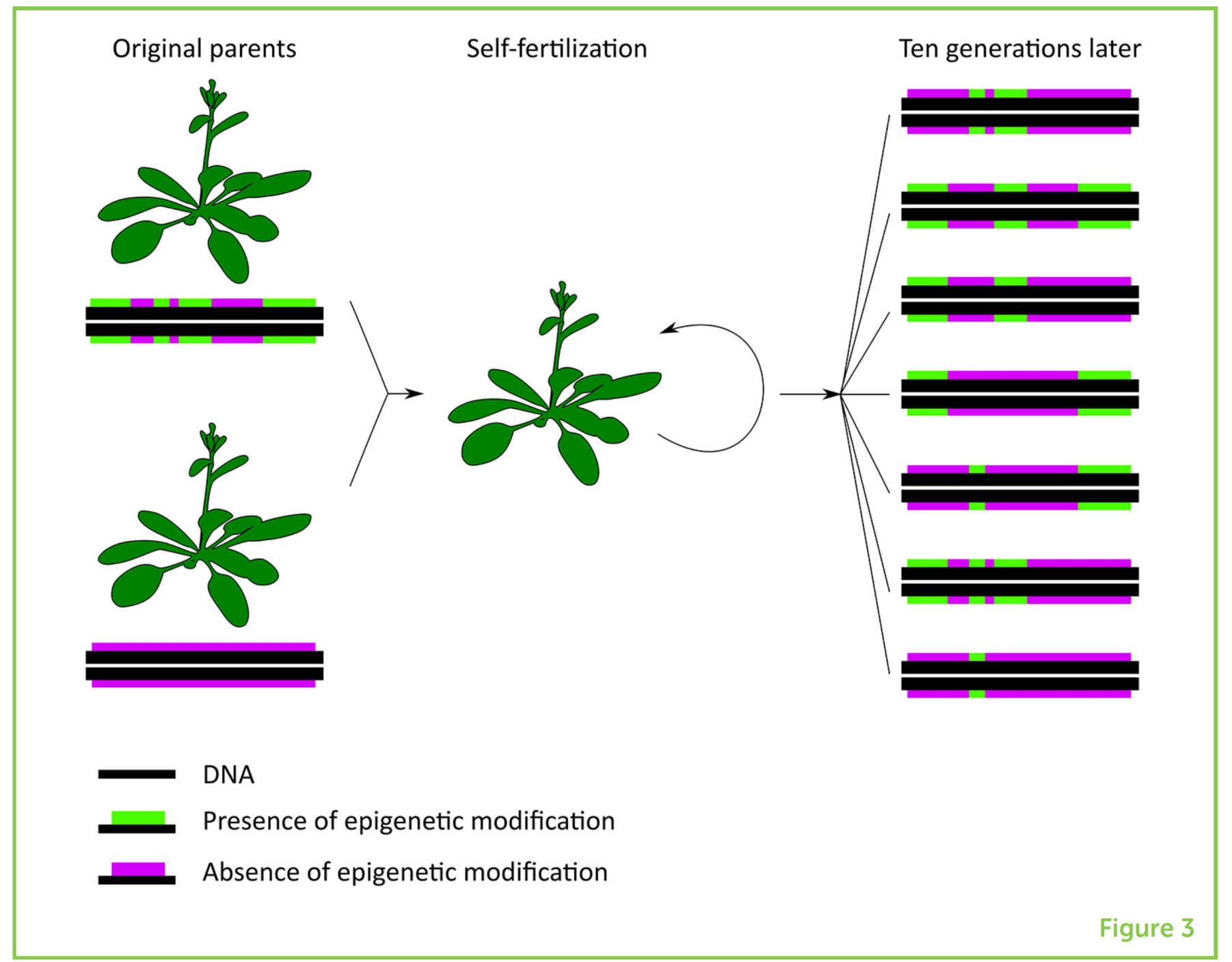

Figura 3: Um experimento epigenético com plantas. Os cientistas cruzaram duas plantas Arabidopsis com sequências de DNA idênticas, mas epigenomas diferentes. As plantas geradas por esse cruzamento se autofecundaram por muitas gerações e mantiveram as diferenças epigenéticas. Essas plantas também eram diferentes umas das outras em certas características, como altura, tempo de floração e tolerância ao sal do solo. 
100. A epigenética pode ajudar, por exemplo, a prever o impacto do clima na produtividade das plantações.

101. Os produtores podem usar o conhecimento da epigenética para desenvolver variedades de colheitas mais resistentes ao estresse.

102. A epigenética pode explicar a origem, o crescimento e a disseminação de certos tipos de câncer.

103. A epigenética pode melhorar o diagnóstico, bem como o tratamento de um câncer.

104. A epigenética também pode oferecer informações sobre como as pessoas respondem de maneiras diferentes ao mesmo tratamento para certas doenças.

105. O número de aplicações está crescendo continuamente e provavelmente continuará a influenciar nossas vidas de muitas maneiras benéficas!

\section{Ciência Aberta}

O arquivo latex para este artigo, juntamente com outros arquivos suplementares, estão disponíveis em [7]. Seja coautor(a) deste artigo, envie sua contribuição para mplobo@uft. edu.br.

\section{Consentimento}

O autor concorda com [8].

\section{Como citar este artigo?}

https://doi.org/10.31219/osf.io/zx4ne https://zenodo.org/record/5137818 


\section{Referências}

[1] Costa M and Johannes F (2020) "Epigenetics: Switching Genes On and Off." Front. Young Minds. 8:554136.

https://doi.org/10.3389/frym.2020.554136

[2] CC. Creative Commons. Attribution 4.0 International (CC BY 4.0) https://creativecommons .org/licenses/by/4.0

[3] Annunziato, A. 2008. "DNA packaging: nucleosomes and chromatin." Nat. Educ. 1:26. https://go.nature.com/3zEY1pU

[4] Sun, H. S., Kennedy, P. J., and Nestler, E. J. 2013. "Epigenetics of the depressed brain: role of histone acethylation and methylation." Neuropsychopharmacology 38:124-37.

https://doi.org/10.1038/npp. 2012.73

[5] Cortijo, S., Wardenaar, R., Colomé-Tatché, M., Gilly, A., Etcheverry, M., Labadie, K., et al. 2014. "Mapping the epigenetic basis of complex traits." Science 343:1145-8.

https://doi.org/10.1126/science.1248127

[6] Kooke, R., Johannes, F., Wardenaar, R., Becker, F., Etcheverry, M., Colot, V., et al. 2015. "Epigenetic basis of morphological variation and phenotypic plasticity in Arabidopsis thaliana." Plant Cell 27:337-48. https://doi.org/10.1105/tpc.114.133025

[7] Lobo, Matheus P. "Open Journal of Mathematics and Physics (OJMP)." OSF, 21 Apr. 2020.

https://doi.org/10.17605/osf.io/6hzyp

[8] Lobo, Matheus P. "Simple Guidelines for Authors: Open Journal of Mathematics and Physics." OSF Preprints, 15 Nov. 2019.

https://doi.org/10.31219/osf .io/fk836 


\section{Colaboração Ciência Aberta}

Matheus Pereira Lobo (autor principal, mplobo@uft.edu.br) $)^{1,2}$ https://orcid.org/0000-0003-4554-1372

${ }^{1}$ Universidade Federal do Tocantins (Brasil)

${ }^{2}$ Universidade Aberta (UAb, Portugal) 